Historic, archived document

Do not assume content reflects current scientific knowledge, policies, or practices. 

United States Department of Agriculture Agricultural Research Service

\section{EFFECTIVENESS OF REPELLENTS AGAINST CULICINE MOSQUITOES 1 /}

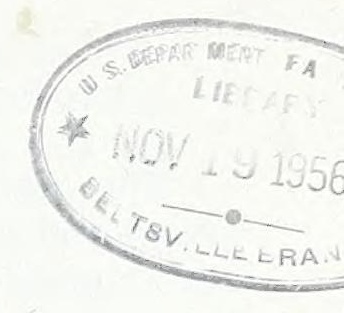
By B. V. Travis, $2 /$ F. A. Morton, $\underline{3}$ / and W. W. Yates $\underline{4} /$

A large number of repellents were tested in the laboratory and field against several culicine mosquitoes from 1942 to 1946. The principal test species were Aedes taeniorhynchus (Wied.), sollicitans (Wlkr。), and a mixed population of Mansonia in Florida. A few tests were made against mountain Aedes and Culiseta in Oregon, Aedes (Aedes) sp. in New Guinea, and several arctic species in Canada and Alaska. Field tests were made against mosquitoes in general in a number of States. Most of the materials included in this report had been found to be outstanding in laboratory tests against Aedes aegypti (L.) (Morton et al. 1 , Travis et al. 3 ), but a few were tested only in the field.

The primary objective of these tests was to find chemicals or formulations that would protect troops from mosquito bites much longer than the standard repellents--dimethyl phthalate, ethyl hexanediol, Indalone, and a 6-2-2 mixture of these respective materials. Many of the preparations were tested only a few times, and then dropped from consideration because they did not give protection at least as long as the better standard materials. The more promising repellents were tested extensively.

A manuscript covering this work was prepared in 1947 but could not be completed for publication at that time. Since then much additional work has been done on repellents for salt-marsh and subarctic Aedes, and reports on these tests have been published (Travis and Smith $\underline{4}$, Smith et al. 2). The previous work, however, contains considerable information that may be of interest to other workers, particularly the results with creams and other formulations. All the tests were made in Florida unless otherwise indicated.

1/ This work was conducted at the Orlando, Fla., laboratory of the former Bureau of Entomology and Plant Quarantine under funds allotted by the former Office of Scientific Research and Development and the Department of the Army. E. F. Knipling, J. H. Cochran, J. H. Robinson, and other members of the laboratory assisted in making the tests, and Lyda Robertson in keeping the records and assembling the data. This laboratory is now a part of the Entomology Research Branch.

2/ Now with Cornell University.

3/ Now with U. S. Army Engineers.

4/ Retired. 


\section{Methods}

The materials were applied to the arms ( $1 / 4$ teaspoonful elbow to wrist) and the legs ( $3 / 8$ teaspoonful knee to ankle) of the test subjects. The treated subjects exposed themselves to mosquitoes in the field to determine how long the materials would prevent bites. The time from treatment to the first bite was called the repellent time. Most of the exposures were continued until more than one bite had been received. With some preparations paired tests were made--concurrently on both arms or legs of the same subject. The routine procedure was to apply each material to several subjects to learn as much as possible of the variation to expect on different individuals. No tests were conducted against salt-marsh Aedes unless the biting rate was in excess of 20 bites on an untreated leg in half a minute. The biting rates for the mountain Aedes were 5 to 12 per half-minute, for Culiseta 0 to 5 , and for Mansonia 5 to 10.

Most of the test materials were liquids, applied undiluted. Some of the most effective ones were later diluted with alcohol or used in other formulations. In some a thickener such as ethyl cellulose or a powder such as bentonite was added to the liquid. In others a pyrethrum insecticide was included, or two or more repellent materials were mixed.

\section{Results}

The results of these tests are presented separately for each mosquito species. Some of the tables include repellent ratios, calculated by dividing the average repellent time of a test material by that of a standard material in concurrent tests and then multiplying by 100. The effectiveness of a chemical could often be compared best by means of this ratio, as the repellent time of any given material varied considerably in different test periods.

Occasionally it was necessary to terminate a test before bites were received. Where the repellent time for such a test exceeded the average for the completed tests with that material, it was included in the average. Such averages are marked in the tables with a plus sign.

Aedes taeniorhynchus

Of the 129 undiluted repellents listed in table 1, 21 gave longer protection against taeniorhynchus than the standard material. The following materials were $11 / 2$ to $21 / 2$ times as effective as the standard: 2 -(xchloro-y-ethylphenyl)ethanol; $\mathrm{N}$-butyl-4-cyclohexene-1,2-dicarboximide; $\mathrm{N}$-isopentylacetanilide; $1,2,3,4$-tetrahydro-2-naphthol; 2,5,7-trimethyl$\overline{3}$-octyne-2,5-diol; and the propyl ester of $\mathbf{N}, \mathbf{N}$-diethylsuccinamic acid. 
The last material has been cleared in pharmacological tests for use on the skin. Such tests with 2,5,7-trimethyl-3-octyne-2,5-diol were inconclusive, and the other four compounds were rejected because of toxicity or skin irritation.

The repellent times obtainedwith the standards during different field trips are shown in table 2. Ethyl hexanediol and mixture 6-2-2 were about equally effective and superior to dimethyl phthalate and Indalone, which were about equally effective. In only one field trip, on July 1.1-14, 1944, was ethyl hexanediol greatly superior to mixture 6-2-2; however, only two tests were made with ethyl hexanediol. If the range of the average repellent times is compared, mixture 6-2-2 is superior to the other standards, with a range of 326 to 161 minutes, giving a ratio of 2.02 as compared with 3.82 for ethyl hexanediol, 5.24 for dimethyl phthalate, and 7.24 for Indalone.

When pyrethrins or $\mathrm{N}$-isobutylundecenamide or both were added to Indalone, ethyl hexanediol, or the ethylene glycol ether of pinene, they had practically no repellent value (table 3 ). Although 1 percent of pyrethrins in Indalone and 0.5 percent in the ethylene glycol ether of pinene gave higher repellent times than the repellents without the pyrethrins, the differences were not statistically significant. The addition of $\mathrm{N}$-isobutylundecenamide, either alone or with the pyrethrins, reduced the average repellent time.

Most of the mixtures of repellents that were tested in the field were superior to the standard (table 4). Only three mixtures had repellent ratios less than 90--dimethyl phthalate plus ethyl hexanediol; 2-phenylcyclohexanol plus 3,4-diethoxybenzaldehyde; and cyclohexyl benzoate plus anisyl alcohol.

The addition of such thickeners as cellulose acetate, ethyl cellulose, methyl cellulose, nitrocellulose, colloidal silica, magnesium, zinc and calcium stearates, a synthetic gum, and the ethyl ester of o-benzoylbenzoic acid failed to increase the repellent time consistently.

In a series of paired tests with various creams and liquids containing volatile solvents and either dimethyl phthalate or a mixture of 2-phenylcyclohexanol and 1,2,3,4-tetrahydro-2-naphthol, the creams were found to be superior to the liquid preparations (table 5). All the preparations containing 2-phenylcyclohexanol and 1,2,3,4-tetrahydro-2-naphthol were superior to those containing dimethyl phthalate. Dimethyl phthalate was more effective in a zinc oxide paste cream than in a cream containing bentonite and calcium stearate; however, this cream was less effective than a vanishing cream containing the same repellent.

Some of the more promising powder-base creams tested in the laboratory against aegypti (Travis et al. 3 ) were tested in the field against taeniorhynchus (table 6). Those prepared with pyrophyllite or tricalcium phosphate were considerably less effective than the standard repellent. This was also true of creams prepared with bentonite except the one 
containing ethyl hexanediol, dimethyl phthalate, and Indalone. With ethyl hexanediol, dimethyl phthalate, and calamine the average repellent time was more than twice that obtained in concurrent tests with undiluted ethyl hexanediol. In two series of tests, one with dimethyl phthalate and one with the mixture 6-2-2, the addition of calcium stearate as a thickener to creams containing bentonite extended the repellent time. The solid repellents butyl sulfone, $\underline{N}$-ethylacetanilide, and $\mathrm{N}$-propylacetanilide gave considerably longer repellent times than the standard.

Cold creams and vanishing creams containing 30 percent of the repellents 2-(2-cyclohexyloxethoxy)ethanol; 3-(2-cyclohexyloxy-1methylethoxy)-2-propanol; ethyl hexanediol; and 2- [2-(3,3,5-trimethylcyclohexyloxy)ethoxy/ethanol were found less effective than the undiluted repellents.

The repellent time of a number of the better repellents was reduced by the addition of a volatile solvent, but the reduction was not in proportion to the dilution (table 7). N-Ethylacetanilide was the only solid material that gave more than $\overline{100}$ minutes' protection.

When the repellents were mixed with nonvolatile solvents, the repellent time was also reduced. Occasionally a few tests with such materials would give a long repellent time. However, the results were not consistent; so only screening-type tests were made with these materiais.

Some tests were made with materials added to dimethyl phthalate. The addition of 2 percent of camphene, 10 percent of a crude alkaloid of Haplophyton, 5 percent of aluminum chloride, or 10 percent of calcium chloride caused little or no increase in repellent time. The last two compounds are said to reduce sweating.

A number of preparations containing ethyl hexanediol, dimethyl phthalate, or Indalone, and some unidentified aromatic substances in powder, petroleum, or beeswax base sent by various agencies were tested in the field. Only the powder-base creams and a beeswax-base cream containing ethyl hexanediol or a mixture of this repellent and dimethyl phthalate gave repellent times that compared favorably with the undiluted repellents. A proprietary product containing 50 percent of the acetate of 2-(2-butoxyethoxy)ethanol was found to be only slightly less effective than this compound undiluted.

\section{Aedes sollicitans}

Of the 12 materials tested against sollicitans, 2- [2-(2-ethylhexyloxy)ethoxy]ethanol, 2-[2-(alpha-methylbenzyloxy)ethoxy]ethanol, and dldibutyl malate were effective for more than 5 hours (table 8). Dimethyl phthalate and Indalone were equally effective against sollicitans as against taeniorhynchus. A proprietary material containing 50 percent of 2-(2butoxyethoxy)ethyl acetate was found in 5 tests to be equally as effective as the undiluted material. 
Miscellaneous Aedes species and Culiseta incidens

The various standard repellents were tested both in the laboratory and in the field against several species of Aedes and $\underline{C}$. incidens in Oregon. Table 9 shows that ethyl hexanediol and the mixture 6-2-2 were generally superior to Indalone or dimethyl phthalate. In four other tests against $\mathrm{A}$. dorsalis the average protection time was 376 minutes with 2 -(2-butoxyethoxy)ethyl acetate, 277 minutes with benzyl benzoate, and 75 minutes with butyl phthalate.

Tests with other compounds against the mixed population containing Aedes sticticus and vexans are summarized in table 10 . In addition 6 tests with an 80:20 mixture of dimethyl phthalate and ethyl hexanediol gave an average repellent time of $368+$ minutes, and 4 tests with a powder-paste cream containing 69 percent of dimethyl phthalate, 151 minutes. Conclusive data were not obtained with many of the repellents, as it was frequently necessary to terminate the tests before a bite was received. The data show that these mountain Aedes are rather easily repelled.

The repellent times against Culiseta incidens are considerably longer than for the various Aedes species (table 9), probably because of the low biting rate prevailing during the test.

Mansonia perturbans (W1kr.) and titillans (W1kr.)

In tests with some of the more promising repellents against a mixed population of these species in Florida, it was found that they are easily repelled and that the standard repellents give good protection (table 11).

Aedes spp.

In 1945 W. V. King and Army coworkers made tests in New Guinea against a mosquito population containing more than 99 percent of a species of Aedes subgenus Aedes near similus (Theob.) and the remainder of Culex halifaxii Theob. and Armigeres sp. (table 12). The biting rates averaged 9.5 on arms and 13 on legs in 5 minutes. The skin was moderately wet with sweat during the tests. Phenethyl ester of 2-methyllactic acid was found to be the best material.

In 1943 H. H. Stage, of the Bureau of Entomology and Plant Quarantine and Terris Moore, of the Office of the Quartermaster General, U. S. Army, made a number of field tests with the standard repellents in Churchill, Canada (table 13). The mosquito population was predominantly Aedes nearcticus Dyar with some cataphylla Dyar. The repellents were applied to the arms and legs by the standard procedure. Mixture 6-2-2 was found to be more effective than any one of its ingredients. A paste made of ethyl hexanediol and bentonite (not included in table) gave an average of only 26 minutes' protection in 9 tests. 
In $1944 \mathrm{Mr}$. Stage conducted similar tests in Alaska against several species of Aedes (table 13). At Nome powder pastes containing dimethyl phthalate were the most effective repellents against a mixed population of nearcticus and riparius $D_{\text {. and }} K_{0}$, and mixture 6-2-2 was superior to any one of its ingredients. In tests near Anchorage with flavescens (Mull.) and species of the stimulans group, he found ethyl hexanediol and dimethyl phthalate to be of equal effectiveness and mixture 6-2-2 to be superior to any one of its ingredients. Powder pastes with dimethyl phthalate and mixture 1-1-1 were much superior to the liquid repellents. In tests near Fairbanks with four repellent creams against mixed populations of cinereus and excrucians (Wlkr.), the one containing $\mathrm{N}$-secbutylphthalimide was the most effective.

C. R. Twinn, of the Canadian Department of Agriculture, made a number of field tests against woodland Aedes in Canada with the four standard repellents. He reported the following repellent times (in minutes): Dimethyl phthalate 267, ethyl hexanediol 329, Indalone 106, mixture 6-2-2 360 .

\section{Miscellaneous Species}

In response to a request from the Bureau's Division of Plant Disease Control, one of the more promising materials, 2-phenylcyclohexanol, was sent to its field employees in 20 States, who compared it with the repellent they were using, which was presumed to contain dimethyl phthalate. When all the reports were summarized, 571 tests with 2-phenylcyclohexanol gave an average repellent time of 114 minutes and 475 tests with the standard gave 106 minutes. Both these figures are lower than those obtained by the research group at Orlando, Fla., but the data seem to be in line with what might be expected from practical tests.

\section{Summary}

From 1942 to 1946 a large number of compounds and formulations were tested in the field against several species of culicine mosquitoes in an effort to find some that would protect troops from mosquito bites longer than the standard repellents.

Against Aedes taeniorhynchus (Wied.) the best materials were 2 -( $\mathrm{x}$-chloro- $\mathrm{y}$-ethylphenyl)ethanol; $\mathrm{N}$-butyl-4-cyclohexene-1,2dicarboximide; $\mathrm{N}$-isopentylacetanilide; 1,2,3,4-tetrahydro-2-naphthol; 2,5,7-trimethyl-3-octyne-2,5-diol; and the propyl ester of $\mathrm{N}, \mathrm{N}$-diethylsuccinamic acid. Only the last one has been cleared in pharmacological tests for use on the skin.

Tests with the four standard repellents--dimethyl phthalate, ethyl hexanediol, Indalone, and mixture 6-2-2--showed that the mixture gave the most consistent results and Indalone the least consistent. 
The addition of pyrethrins or $\mathrm{N}$-isobutylundecenamide failed to increase the repellent time of Indalone, ethyl hexanediol, or ethylene glycol ether of pinene. In most tests mixtures of the better repellents were more effective than the standard ethyl hexanediol.

The addition of thickeners failed to increase the protection time of repellents, but generally powder-base creams to which thickeners had been added were more effective than the liquid repellents. Likewise, repellents formulated with a vanishing or cold cream were not effective.

The repellent times were much longer with the mountain Aedes, Culiseta, and Mansonia than with the salt-marsh Aedes, but this may have been due to the low biting rates prevailing during the tests.

\section{Literature Cited}

(1) Morton, F. A., Travis, B. V., and Linduska, J. P.

1947. Evaluation of materials as mosquito repellents. Part V. In Results of screening tests with materials evaluated as insecticides, miticides, and repellents at the Orlando, Fla., laboratory April 1942 to April 1947. U. S. Bur. Ent. and Plant Quar. E-733, pp. 10-11.

(2) Smith, Carroll N., Cole, M. M., Lloyd, George W., and Selhime, Allen. 1952. Mosquito-repellent mixtures. Jour. Econ. Ent. 45: 805-809.

(3) Travis, B. V., Morton, F. A., Jones, Howard A., and Robinson, J. H. 1949. The more effective mosquito repellents tested at the Orlando, Fla., laboratory 1942-47. (Scientific Note) Jour. Econ. Ent. 42: 686-694.

(4) and Smith, Carroll N.

1951. Mosquito repellents selected for use on man. (Scientific Note) Jour. Econ. Ent. 44: 428-429. 
Table 1.--Effectiveness of repellents against Aedes taeniorhynchus.

\begin{tabular}{l|c|c|c|c}
\hline Material & $\begin{array}{c}\text { Orlando } \\
\text { No. }\end{array}$ & Tests & $\begin{array}{c}\text { Average } \\
\text { repellent } \\
\text { time }\end{array}$ & $\begin{array}{c}\text { Repellent } \\
\text { ratio }\end{array}$ \\
\hline
\end{tabular}

Number Minutes

Number Minutes

Acetamide, 2-butoxy-N-pentyl-

-butoxy- $\overline{\mathrm{N}}$-cyclohexyl-

$\mathrm{N}$-cyclohexyl-2-(2-methylallyloxy)-

Acetanilide, $\overline{2}$-butoxy-

$$
\frac{\mathrm{N}-\text { butyl- }}{\mathrm{N}} \text {-isopentyl- }
$$

Acetoacetic acid, cyclohexyl ester

Acetophenone, $3^{\prime}, 4^{\prime}$-dichloro-

$$
\begin{aligned}
& 4^{\prime} \text {-'ethoxy- } \\
& 4^{\prime} \text {-methoxy- }
\end{aligned}
$$

Adipic acid, diethyl ester

Anisole, o-phenyl-

Anisyl alcohol

Benzaldehyde, $\underline{p}$-propoxy-

Benzamide, N, $\underline{N}$-diethyl-

Benzyl alcohol, alpha-ethoxymethyl-

Benzyl benzoate

Benzyl ether

Bicyclo 2.2.1] hept-5-ene-2,3-dicarboximide; N(mixed)amyl-

Bicyclo 2.2.1 hept-5-ene-2,3-dicarboxylic acid, diethyl ester

cis-, dimethyl ester (dimethyl carbate)

2-Biphenylamine

gamma-Cadinene

Cinnamaldehyde, alpha-pentyl-

Cinnamic acid, isopropyl ester

methyl ester

propyl ester

Citric acid, tributyl ester

acetate

Cyclohexaneacetic acid, alpha-cyano-, ethyl ester

Cyclohexanecarboxylic acid, 1-hydroxy-, cyclopentyl ester

1,2-Cyclohexanedicarboxylic acid, diethyl ester

Cyclohexane-2-hexenoic acid, methyl ester

Cyclohexanol, 2-cyclohexyl-

$$
\begin{aligned}
& \text { 4-(1,1-dimethylpropyl)- } \\
& \text { 2,4-dipentyl- } \\
& \text { 2-phenyl- }
\end{aligned}
$$

3-Cyclohexene-1-carbonitrile, 5,5-dimethyl-2-

(1-methylpropenyl)-

4-Cyclohexene-1,2-dicarboximide, $\mathrm{N}$-butyl-

?-Dioxane, 4-(p-methoxyphenyl)-5-methyl-

Diphenylamine, N-pentyl-

$$
\text { 5-methyl-5-nitro-2-propyl- }
$$

Elemol

Ethanol, 2-(benzyloxy)2 - [is $(1,1$-dimethylpropyl)phenoxy]-

2-(2-butoxyethoxy)-, acetate
925

614

1881

1714

2484

5528

6230

479

1029

227

342

236

1170

5518

1197

338

523

2269

1492

4132

3916

67

209

658

2026

579

2024

394

204

205

4999

6133

5567

2000

1023

431

421

2133

1651

4145

5533

7102

$\begin{array}{rrr}8 & 312 & 125 \\ 18 & 362 & 145 \\ 3 & 217 & 80 \\ 5 & 175 & 65 \\ 10 & 359 & 115 \\ 11 & 290 & 254 \\ 4 & 102 & 89 \\ 3 & 110 & 31 \\ 2 & 82 & 48 \\ 4 & 84 & 50 \\ 13 & 96 & 32 \\ 4 & 5 & 1 \\ 20 & 93 & 50 \\ 7 & 110 & 96 \\ 1 & 437 & -- \\ 7 & 69 & 20 \\ 2 & 61 & 36 \\ 8 & 91 & 24\end{array}$

203

120

101

208

116

82

83

$172+$

91

287

55

133

148

76

155

96

100

159

147

51

$252+$

61

181

62

37

13

157

185

62

126

25

45

65

115

254

89

31

48

50

32
1

50

96

20

36

24

62

69

23

49

55

54

91

16

38

42

67

136

84

59

67

51

14

94

1040

447

170
22

159

54

32

3

48

43

18

47 
Table 1.--Continued

\begin{tabular}{l|c|c|c|c}
\hline Material & $\begin{array}{c}\text { Orlando } \\
\text { No. }\end{array}$ & Tests & $\begin{array}{c}\text { Average } \\
\text { repellent } \\
\text { time }\end{array}$ & $\begin{array}{c}\text { Repellent } \\
\text { ratio }\end{array}$ \\
\hline
\end{tabular}

Ethanol, 2-(p-tert-butylphenoxy)-

$2-(\bar{x}-$ chloro-y-ethylphenyl)-

$\underline{\text { Number }}$ Minutes

$2-(\overline{2}-$ cyclohexyloxyethoxy $)-$

103

2-N-ethylanilino-

2-(alpha-methylbenzyloxy)-

2 - [2-(alpha-methylbenzyloxy)ethoxy]-

2-(3-methyl-2-norcamphanylmethoxy)-

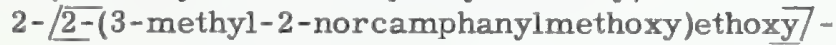

2-phenoxy-, acetate

$2,2^{\prime}$-thiodi-, diacetate

$2-[2-(3,3,5$-trimethylcyclohexyloxy)ethoxy -

Ether, $\underline{p}-(1,1-$ dimethylpropyl)phenyl pentyl

pentyl phenyl

pentyl xylyl

butyl phenyl

253

53

421

373

1463

164

166

773

774

2145

5542

376

423

441

438

446

Ethylene glycol, alkyl benzyl ethers

4723

2-Furoic acid, cyclohexyl ester

Geraniol

1487

1,3-Hexanediol, 2-ethyl- (standard)

375

Hydracrylic acid, 3-phenyl-, ethyl ester

6216

Hydrocinnamic acid, alpha, beta-epoxy-beta-

methyl-, ethyl ester

Indalone

Isobutyl sulfone

Lactic acid, butyl ester

ethyl ester

2-methyl-, benzyl ester

bornyl ester

phenethyl ester

Lauric acid, pentyl ester

$$
\begin{aligned}
& 2 / \bar{p}-(1,1 \text {-dimethylpropyl }) \text { phenoxy/ethyl ester } \\
& \text { isopropyl ester, crude }
\end{aligned}
$$

Maleic acid, dipentyl ester

2947

9
5529

397

395

1654

1653

1650

425

422

1094

418

Malic acid, dl-, dibutyl ester

337

Mandelic acid, butyl ester

ethyl ester

isopropyl ester

methyl ester

1643

1788

1787

Myristic acid, isopropyl ester, crude

1095

445

Naphthalene, 2-pentyloxy-

5563

2-Naphthol, 1,2,3,4-tetrahydro-

3-Octyne-2,5-diol, 2,5,7-trimethyl-

Oils, bay

camphor, ethereal

citronella

eucalyptus

juniper berry 


\begin{tabular}{|c|c|c|c|c|}
\hline Material & $\begin{array}{c}\text { Orlando } \\
\text { No. }\end{array}$ & Tests & $\begin{array}{c}\text { Average } \\
\text { repellent } \\
\text { time }\end{array}$ & $\begin{array}{l}\text { Repellent } \\
\text { ratio }\end{array}$ \\
\hline
\end{tabular}

Number Minutes

Oleic acid, pentyl ester

Oxalic acid, dipentyl ester

2-Pentanol, 4-(3-hydroxypropoxy)-2-methyl-

Phenethyl alcohol, $\underline{p}$-chloro-

$$
\text { p-isopropyl- }
$$

Phenol, $\underline{p}-(1,1$-dimethylpropyl-, acetate

Phosphoric acid, tributyl ester

Phthalic acid, diethyl ester

$$
\text { dimethyl ester (standard) }
$$

Phthalimide, N-sec-butyl-

Pinene, ether with ethylene glycol

Propanediol, $x-(2$-ethylbutoxy)-

1,2-Propanediol, 3-isopentyloxy-

Propionic acid, 2-benxyloxy-2-methyl-, benzyl ester

ethyl ester

Propanol, butoxypolypropyleneoxy-

2-Propanol, 3-(2-cyclohexyloxy-1-methylethoxy)1 - [2-(3,3,5-trimethylcyclohexyloxy)propoxy] -

Propionic acid, diester with 1,5-pentanediol

Ricinoleic acid, acetyl-, butyl ester

Salicylic acid, pentyl ester isopentyl ester

Sebacic acid, dibutyl ester

Stearic acid, pentyl ester butyl ester

Succinamic acid, $\mathrm{N}, \mathrm{N}$-diethy1-, propyl ester

$$
\bar{N}, \bar{N} \text {-dipropyl-, ethyl ester }
$$

Succinic acid, 2-cyano-3-methyl-, diethyl ester

Tartaric acid, dibutyl ester diisopropyl ester

Toluenesulfonamide, $\mathbb{N}, \mathbf{N}$-dibutyl-

Undecanoic acid, hydroxy-, lactone

Undecyl alcohol

$\begin{array}{rrrr}417 & 6 & 56 & 16 \\ 419 & 8 & 94 & 27 \\ 169 & 3 & 91 & 26 \\ 2719 & 2 & 231 & 53 \\ 1774 & 18 & 207 & 77 \\ 420 & 13 & 108 & 31 \\ 399 & 2 & 149 & 42 \\ 329 & 4 & 116 & 46 \\ 262 & 233 & 161 & 58 \\ 2419 & 10 & 77 & 68 \\ 558 & 34 & 229+ & 92 \\ 1442 & 6 & 315 & 117 \\ 3554 & 4 & 422 & 98 \\ 1910 & 7 & 75 & 28 \\ 1911 & 10 & 74 & 27 \\ 163 & 6 & 298 & 85 \\ 374 & 28 & 310 & 100 \\ 1123 & 20 & 255 & 102 \\ 6154 & 8 & 95 & 83 \\ 400 & 1 & 27 & 8 \\ 334 & 8 & 56 & 16 \\ 378 & 7 & 67 & 19 \\ 393 & 2 & 52 & 15 \\ 430 & 11 & 64 & 18 \\ 398 & 5 & 39 & 11 \\ 6168 & 10 & 182 & 160 \\ 6252 & 10 & 158 & 138 \\ 5611 & 8 & 20 & 18 \\ 396 & 4 & 69 & 20 \\ 3572 & 13 & 70 & 25 \\ 424 & 3 & 21 & 6 \\ 751 & 2 & 189 & 43 \\ 330 & 3 & 36 & 10 \\ & & & \end{array}$

16

27

26

53

77

31

42

46

58

68

92

117

98

28

27

85

100

02

16

19

15

18

11

160

38

18

20 
Table 2.--Average repellent times obtained with several standard repellents against Aedes taeniorhynchus in different field trips.

\begin{tabular}{l|l|c|c|c|c|c|c|c}
\hline \multirow{2}{*}{ Date of tests } & \multicolumn{2}{|c|}{ Ethyl hexanediol } & Dimethyl phthalate & \multicolumn{2}{|c|}{ Indalone } & Mixture 6-2-2 \\
\cline { 2 - 6 } & Tests & $\begin{array}{c}\text { Repellent } \\
\text { time }\end{array}$ & Tests & $\begin{array}{c}\text { Repellent } \\
\text { time }\end{array}$ & Tests & $\begin{array}{c}\text { Repellent } \\
\text { time }\end{array}$ & $\begin{array}{c}\text { Tests } \\
\text { time }\end{array}$ \\
\hline
\end{tabular}

Number Minutes Number Minutes Number Minutes Number Minutes

1942

June $\overline{29-30}$

Sept. 17-22

Oct. 15-23

1943

June $\overline{10-19}$

July $12-13$

16-17

22

Aug. 23

Sept. 10

$$
\begin{aligned}
& \text { June } \frac{1944}{2-6} \\
& 21-23 \\
& \text { July } 11-14 \\
& 19-21 \\
& 26-28
\end{aligned}
$$

Aug. 3-5

16-18

July $\frac{1945}{1-\text { Aug. } 31}$

$8 \quad 114$

251

267

436

337

431

250

--

114

22

83

262

200

246

156

248

12

69

212

Sept. $\frac{1946}{10}$

Total or average

\begin{tabular}{rrrrrrrr}
4 & 181 & 4 & 206 & -- & -- & 4 & 161 \\
\hline 166 & 265 & 233 & 161 & 162 & 162 & 88 & 250
\end{tabular}


Table 3.--Effect of adding pyrethrins and/or $\mathrm{N}$-isobutylundecenamide on the repellent time of repellents against Aedes taeniorhynchus.

\begin{tabular}{l|c|c|c|c}
\hline Repellent & Pyrethrins & $\begin{array}{c}\text { N-Isobutyl- } \\
\text { undecenamide }\end{array}$ & Tests & $\begin{array}{c}\text { Average } \\
\text { repellent time }\end{array}$ \\
Percent & $\underline{\text { Percent }} \underline{\text { Number }} \underline{\text { Minutes }}$
\end{tabular}

Ethylene glycol ether

of pinene

--
--
5
1
0.5
1

--
2
--
--
-
2

4
3
7
15
12
3

Ethyl hexanediol
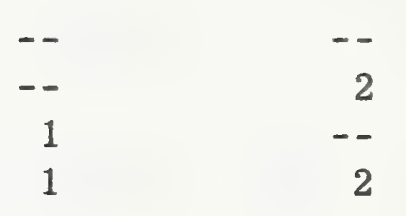

12
4
4
3

Indalone

$\begin{array}{rr}-- & -- \\ -- & 2 \\ 1 & -- \\ 1 & 2\end{array}$

Pyrethrins check $\underline{1}$ /

12
4
4
4

1/ From a 20-percent pyrethrum concentrate in equal parts of white petroleum oil and the sodium salt of bis(2-ethylhexyl) sulfosuccinate. 
Table 4.--Effectiveness of mixtures of repellents against Aedes taeniorhynchus.

\begin{tabular}{|c|c|c|c|}
\hline $\begin{array}{c}\text { Repellent mixture } \\
\text { (figures after ingredients } \\
\text { indicate percent) }\end{array}$ & Tests & $\begin{array}{l}\text { Average } \\
\text { repellent time }\end{array}$ & $\begin{array}{l}\text { Repellent } \\
\text { ratio }\end{array}$ \\
\hline & Number & Minutes & \\
\hline \multicolumn{4}{|l|}{ Cyclohexyl benzoate plus-- } \\
\hline Anisyl alcohol 50 & 1 & 133 & 31 \\
\hline Isopropyl cinnamate 50 & 9 & 107 & 94 \\
\hline \multicolumn{4}{|l|}{ Dimethyl phthalate plus-- } \\
\hline Coumarin 40 & 8 & 281 & 113 \\
\hline Ethyl hexanediol 20 & 28 & 258 & 78 \\
\hline \multicolumn{4}{|l|}{ Ethylhexanediol and Indalone } \\
\hline $33.3 \mathrm{each}$ & 29 & 313 & 109 \\
\hline 25 each & 6 & 360 & 107 \\
\hline 20 each & 89 & 250 & 92 \\
\hline 10 each & 26 & 253 & 93 \\
\hline
\end{tabular}

Ethyl hexanediol plus --

Butyl sulfone 25

Indalone 75

Indalone plus - -

Butyl sulfone 25

Coumarin, saturated

2-Phenylcyclohexanol plus--

Cyclohexyl benzoate 50

2-Cyclohexylcyclohexanol 30 
Table 5.--Results of paired tests with liquid and cream formulations of repellents against Aedes taeniorhynchus.

\begin{tabular}{|c|c|c|c|}
\hline $\begin{array}{l}\text { Composition of repellent } \\
\text { (figures after ingredients indicate percent) }\end{array}$ & Form & Tests & $\begin{array}{l}\text { Average } \\
\text { repellent ti }\end{array}$ \\
\hline & & Number & Minutes \\
\hline $\begin{array}{l}\text { 2-Phenylcyclohexanol } 70+1,2,3,4 \text {-tetrahydro-2- } \\
\text { naphthol } 30\end{array}$ & Liquid & 10 & 191 \\
\hline $\begin{array}{l}\text { Dimethyl phthalate } 65+\text { bentonite } 33+\text { calcium } \\
\text { stearate } 2\end{array}$ & Cream & 10 & 142 \\
\hline $\begin{array}{l}\text { 2-Phenylcyclohexanol } 35+1,2,3,4 \text {-tetrahydro- } \\
2 \text {-naphthol } 15 \text { plus-- }\end{array}$ & & & \\
\hline $1-$ Hexanol 50 & Liq & 16 & 148 \\
\hline Zinc oxide 50 & Cream & 16 & 307 \\
\hline $\begin{array}{l}1 \text {-Hexanol } 50 \\
\text { imethyl phthalate } 65+\text { bentonite } 33+\end{array}$ & Liquid & 19 & 310 \\
\hline calcium stearate 2 & Cream & 19 & 182 \\
\hline
\end{tabular}

2-Phenylcyclohexanol $42+1,2,3,4$-tetrahydro2-naphthol 18 plus--

1 -Hexanol 40

Liquid

Tegin $25+$ Tween $605+$ water 10 Sample 1 Cream 8

Dimethyl phthalate $65+$ bentonite $33+$ Sample 2 Cream 8 calcium stearate 2

Cream

Dimethyl phthalate 50 plus --

1 Hexanol 50

Zinc oxide 50 Sample 1

Liquid 10

Cream 10

Sample 2

Cream

19

Dimethyl phthalate $65+$ bentonite $33+$

Cream 19

Dimethyl phthalate 60 plus --

1-Hexanol 40

Liquid

9

Tegin $10+$ Tween 605 + water 25

Cream

Cream

9

Dimethyl phthalate $65+$ bentonite $33+$ calcium stearate 2 


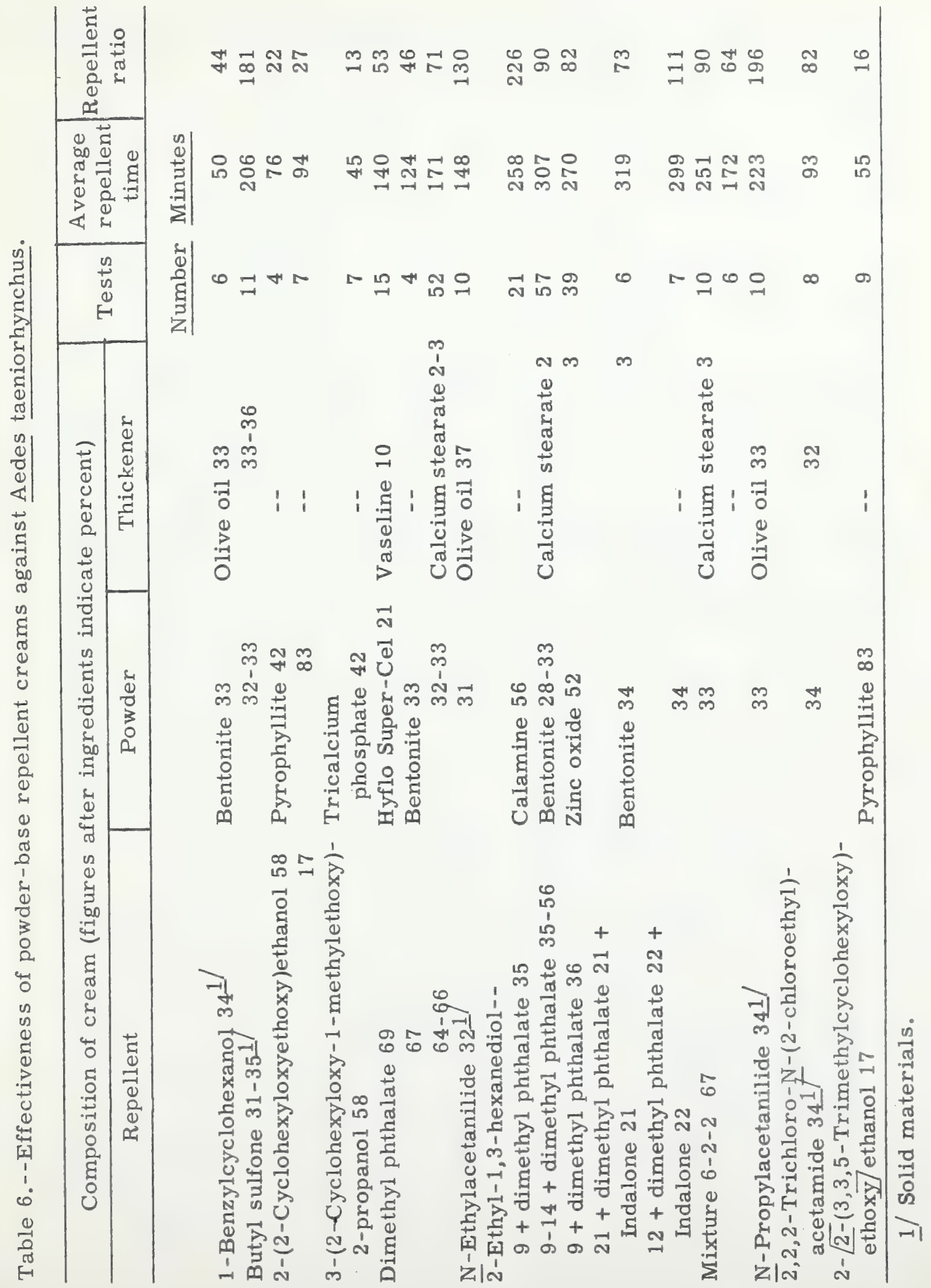


Table 7.--Effectiveness of repellents in volatile solvents against Aedes taeniorhynchus.

Repellent

1-Benzylcyclohexanol-/

Butyl sulfone 2 /

2-(2-Cyclohexyloxyethoxy)ethanoI

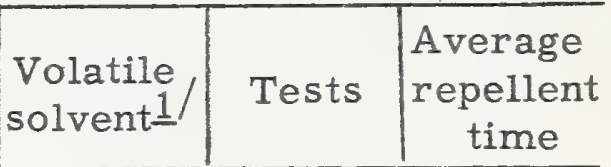

(2-Cyclohexyloxyethoxy) ethanol

2-(2-Cyclohexyloxypropoxy)-1-propanol

Percent Number

Minutes $68 \frac{3}{4} /$ 63

0

0

50

70

0

50

70

Dimethyl phthalate

Dimethyl phthalate $75 \%$ + ethyl hexanediol $9 \%$ N-Ethylacetanilide 2 ,

16 $61 \frac{5}{3}$ 683

Ethyl hexanediol

Indalone

2-[2-(3-Methyl-2-norcamphanylmethoxy)ethoxy/ethanol

$\begin{array}{rr}0 & 6 \\ 75 & 4 \\ 68 & 3\end{array}$

1/ Ethanol unless otherwise indicated.

$\overline{2} /$ Solid material.

3 / Benzyl acetate.

4/ 1-Hexanol.

5/ Acetone. 
Table 8.--Effectiveness of repellents against Aedes sollicitans.

\begin{tabular}{|c|c|c|c|}
\hline Repellent & $\begin{array}{c}\text { Orlando } \\
\text { No. }\end{array}$ & Tests & $\begin{array}{c}\text { Average } \\
\text { repellent } \\
\text { time }\end{array}$ \\
\hline & & Number & Minutes \\
\hline Adipic acid, diethyl ester & 342 & 3 & 143 \\
\hline Ethanol, 2-(2-butoxyethoxy)-, acetate & 170 & 32 & 107 \\
\hline $2-\underline{2}-(2-$ ethylhexyloxy)ethoxy $]-$ & 300 & 6 & 308 \\
\hline $2-(2-$ hexyloxyethoxy $)-$ & 301 & 3 & 217 \\
\hline 2-(alpha-methylbenzyloxy)- & 164 & 27 & 159 \\
\hline 2-(alpha-methylbenzyloxy)-, acetate & 165 & 4 & 261 \\
\hline $2-[2-($ alpha - methylbenzyloxy)ethoxy $]-$ & 166 & 2 & 344 \\
\hline Indalone & 9 & 38 & $157+$ \\
\hline Malic acid, dl-dibutyl ester & 337 & 11 & $348+$ \\
\hline Phthalic acid, dibutyl ester & 283 & 3 & 14 \\
\hline $\begin{array}{c}\text { dimethyl ester } \\
\text { 2-Propanol, 1-(tetrahydro-2,6-dimethyl-3- }\end{array}$ & 262 & 14 & 182 \\
\hline pyranylmethoxy)- & 299 & 15 & 259 \\
\hline
\end{tabular}




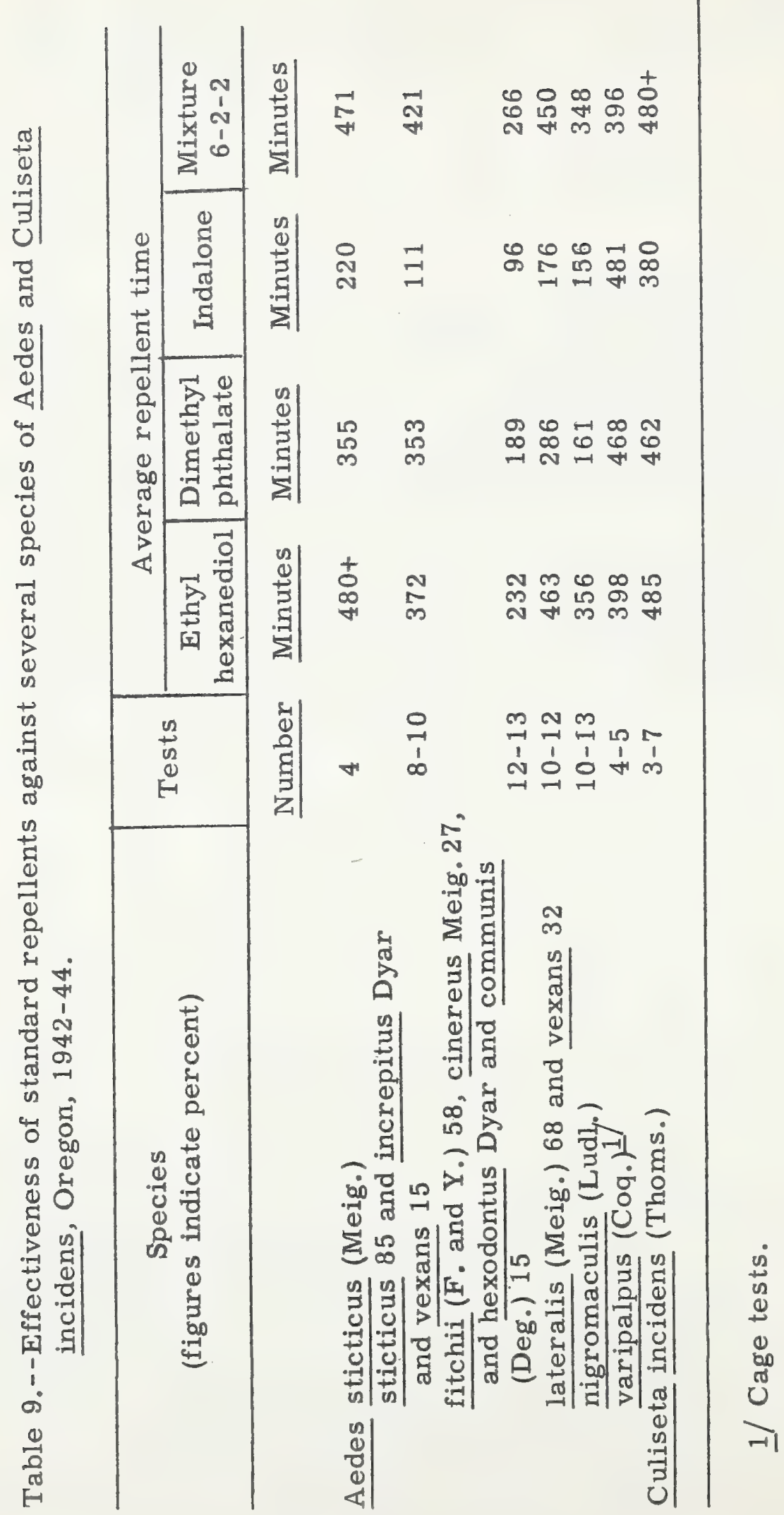


Table 10.-- Protection obtained with repellents against a population containing 68 percent of Aedes sticticus and 32 percent of vexans, Oregon 1942-44.

\begin{tabular}{|c|c|c|c|}
\hline Repellent & $\begin{array}{c}\text { Orlando } \\
\text { No. }\end{array}$ & Tests & $\begin{array}{c}\text { Average repellent } \\
\text { time }\end{array}$ \\
\hline & & Number & Minutes \\
\hline Acetoacetic acid, cyclohexyl ester & 6230 & 3 & 152 \\
\hline Anisyl alcohol & 1170 & 2 & $388+$ \\
\hline Anthranilic acid, propyl ester & 2576 & 3 & 330 \\
\hline Benzaldehyde, 3,4-diethoxy- & 2069 & 2 & $323+$ \\
\hline o-ethoxy- & 1358 & 4 & 116 \\
\hline Benzoic acid, cyclohexyl ester & 2126 & 2 & 255 \\
\hline tetrahydrofurfuryl ester & 4567 & 4 & 179 \\
\hline Benzyl alcohol, o-methoxy- & 5521 & 4 & 180 \\
\hline Benzyl benzoate & 523 & 4 & 324 \\
\hline Benzyl ether & 2269 & 4 & 83 \\
\hline $\begin{array}{c}\text { Bicyclo } 2.2 .17 \text { hept-5-ene-2,3-dicarboxylic acid, } \\
\text { diethyl ester }\end{array}$ & 4132 & 5 & 262 \\
\hline cis-, dimethyl ester (dimethyl carbate) & 3916 & 4 & 228 \\
\hline Cyclohexaneacetic acid, alpha-cyano-, ethyl ester & 4999 & 3 & 127 \\
\hline Cyclohexanecarboxylic acid, 1-hydroxy-, & & & \\
\hline cyclopentyl ester & 6133 & 3 & $293+$ \\
\hline 1,2-Cyclohexanedicarboxylic acid, diethyl ester & 5567 & 3 & 292 \\
\hline Cyclohexanol, 2-phenyl- & 2133 & 2 & 355 \\
\hline 4-Cyclohexane-1,2-dicarboximide, $N$-butyl- & 4145 & 3 & $355+$ \\
\hline m-Dioxane, 4-(p-methoxyphenyl)-5-methyl- & 5533 & 4 & 164 \\
\hline 5-methyl-5-nitro-2-propyl- & 7102 & 3 & 143 \\
\hline 5-m-Dioxanol, 2-hexyl- & 5024 & 4 & $349+$ \\
\hline 1,4-Dioxaspiro $[5.5]$ undecan-3-ol, 7-methyl- & 5032 & 4 & 258 \\
\hline 1,3-Dioxolane, 2-hexyl-4-(methoxymethyl)- & 5027 & 3 & $290+$ \\
\hline Ethanol, 2-(2-butoxyethoxy)-, acetate & 170 & 7 & 256 \\
\hline 2-phenoxy-, acetate & 2145 & 3 & 168 \\
\hline 2,2'-thiodi-, diacetate & 5542 & 3 & 185 \\
\hline Ethylene glycol, alkyl benzyl ethers & 4723 & 3 & 267 \\
\hline Hydracrylic acid, 3-phenyl-, ethyl ester & 6216 & 3 & $355+$ \\
\hline $\begin{array}{l}\text { Hydrocinnamic acid, alpha, beta-epoxy-beta-methyl-, } \\
\text { ethyl ester }\end{array}$ & 2947 & 3 & $273+$ \\
\hline Isobutyl sulfone & 5529 & 3 & 168 \\
\hline Lactic acid, 2-methyl-, phenethyl ester & 1650 & 4 & $289+$ \\
\hline Malic acid, dl-, dibutyl ester & 337 & 4 & $264+$ \\
\hline 2-Naphthol, $\overline{1}, 2,3,4$-tetrahydro- & 5563 & 3 & $365+$ \\
\hline 3-Octyne-2,5-diol, 2,5,7-trimethyl- & 7139 & 3 & $372+$ \\
\hline Phenethyl alcohol, $\underline{p}$-isopropyl- & 1774 & 4 & 260 \\
\hline Phthalic acid, diallyl ester & 2574 & 4 & 55 \\
\hline dibutyl ester & 283 & 8 & 46 \\
\hline Phthalimide, N-sec-butyl- & 2419 & 3 & 42 \\
\hline 1,2-Propanediol, 3-(1,3-dimethylbutoxy)- & 4562 & 4 & 269 \\
\hline 2-Propanol, 3-(2-cyclohexyloxy-1-methylethoxy)- & 374 & 3 & $266+$ \\
\hline Propionic acid, diester with 1,5-pentanediol & 6154 & 4 & 214 \\
\hline Succinamic acid, $\mathbf{N}, \mathbf{N}$-diethyl-, propyl ester & 6168 & 3 & $363+$ \\
\hline$\overline{\mathbf{N}}, \overline{\mathbf{N}}$-dipropyl-, ethyl ester & 6252 & 3 & $362+$ \\
\hline Succinic acid, 2-cyaño-3-methyl-, diethyl ester & 5611 & 3 & 42 \\
\hline Undecenoic acid & 2065 & 2 & $388+$ \\
\hline
\end{tabular}


Table 11.--Protection obtained with repellents against a mixed population of Mansonia perturbans and titillans, 1945.

\begin{tabular}{|c|c|c|}
\hline $\begin{array}{c}\text { Repellent } \\
\text { (figures after ingredients } \\
\text { indicate percent) }\end{array}$ & Tests & $\begin{array}{l}\text { Average } \\
\text { repellent } \\
\text { time }\end{array}$ \\
\hline & Number & Minutes \\
\hline Dimethyl phthalate & 12 & 243 \\
\hline \multicolumn{3}{|l|}{ Dimethyl phthalate plus-- } \\
\hline Bentonite 30 and calcium stearate 20 & 8 & 288 \\
\hline Calcium stearate 35 & 8 & 182 \\
\hline $\begin{array}{l}\text { Ethyl hexanediol } 13 \text {, bentonite } 33 \text {, and } \\
\text { calcium stearate } 2\end{array}$ & 12 & 308 \\
\hline $\begin{array}{l}\text { Ethyl hexanediol } 9 \text {, zinc oxide } 52 \text {, and } \\
\text { calcium stearate } 3\end{array}$ & 4 & 289 \\
\hline $\begin{array}{l}\text { Ethyl hexanediol } 8 \text {, zinc oxide } 58 \text {, and } \\
\text { calcium stearate } 3\end{array}$ & 10 & 259 \\
\hline Zinc oxide 50 & 6 & 267 \\
\hline Zinc stearate 30 & 8 & 201 \\
\hline Ethyl hexanediol & 10 & 406 \\
\hline Mixture 6-2-2 & 11 & 336 \\
\hline 2-Phenylcyclohexanol & 12 & 328 \\
\hline \multicolumn{3}{|l|}{ 2-Phenylcyclohexanol plus-- } \\
\hline Bentonite 32 and calcium stearate 3 & 8 & 295 \\
\hline Bentonite 6 and calcium stearate 31 & 8 & 313 \\
\hline
\end{tabular}


Table 12.--Effectiveness of repellents against a population consisting mainly of Aedes (Aedes) sp., New Guinea, 1945.

\begin{tabular}{|c|c|c|c|c|}
\hline \multirow{2}{*}{ Repellent } & \multirow{2}{*}{$\begin{array}{c}\text { Orlando } \\
\text { No. }\end{array}$} & \multirow{2}{*}{ Tests } & \multicolumn{2}{|c|}{$\begin{array}{c}\text { Average repellent } \\
\text { time to-- }\end{array}$} \\
\hline & & & $\begin{array}{l}\text { First } \\
\text { bite }\end{array}$ & $\begin{array}{l}\text { Second } \\
\text { bite }\end{array}$ \\
\hline & & Number & Minutes & Minutes \\
\hline Benzyl ether & 2269 & 2 & 120 & 157 \\
\hline Cinnamic acid, isopropyl ester & 2026 & 1 & 47 & 60 \\
\hline (cream) & 2026 & 2 & 150 & 165 \\
\hline Cyclohexanol, 2-phenyl- & 2133 & 5 & 150 & 165 \\
\hline Lactic acid, 2-methyl-, phenethyl ester & 1650 & 2 & $187+$ & $202+$ \\
\hline Malic acid, dl-, dibutyl ester & 337 & 2 & 135 & 135 \\
\hline Phthalimide, $\mathrm{N}$-sec-buty1- & 2419 & 2 & 120 & 150 \\
\hline Succinimide, $\overline{\mathbf{N}}-\overline{\text { pentyl- }}$ & 2971 & 2 & $150+$ & $180+$ \\
\hline Mixture 6-2-2 & $M-1473$ & 6 & 135 & 190 \\
\hline
\end{tabular}


Table 13.--Results with repellents against mixed populations of arctic and subarctic Aedes spp., Canada 1943, Alaska 1944.

\begin{tabular}{c|c|c}
\hline $\begin{array}{c}\text { Repellent } \\
\text { (figures after ingredients } \\
\text { indicate percent) }\end{array}$ & Tests & $\begin{array}{c}\text { Average } \\
\text { repellent time }\end{array}$ \\
\hline & Number & Minutes \\
\hline
\end{tabular}

Tests at Churchill, Canada

Dimethyl phthalate

Ethyl hexanediol

Indalone

Mixture 6-2-2
10
94

108

78

130

Tests at Nome, Alaska

Dimethyl phthalate

Dimethyl phthalate 65 , bentonite 33 , and calcium stearate 2

Dimethyl phthalate 49 , zinc oxide 49 , and bentonite 2

Ethyl hexanediol

Indalone

Mixture 1-1-1

Mixture 6-2-2

Tests at Anchorage, Alaska

Dimethyl phthalate

Dimethyl phthalate 67 , bentonite 31 , and calcium stearate 2

Dimethyl phthalate 49 , zinc oxide 49 , and bentonite 2

Ethyl hexanediol

Indalone

Isopropyl cinnamate

Mixture 1-1-1

Mixture 1-1-1 64, bentonite 33, and calcium stearate 3

Mixture 1-1-1 43, zinc oxide 51, and bentonite 6

Tests at Fairbanks, Alaska 

U. S. DEPT. OF AGR. LIBRARY

BELTSVILLE BR.

LIBRARIAN

10-24-55 PLAN INDUSTRY STA.

33 BELTSVILLE, HD. 